$\begin{array}{r}\text { DARMABAKTI CENDEKIA: } \\ \text { Journal of Community Service and Engagements } \\ \text { www.e-journal.unair.ac.id/index.php/DC } \\ \hline\end{array}$

\section{OPTIMIZATION OF DSME THROUGH INCREASED KNOWLEDGE OF PREVENTION OF COMPLICATIONS AND DIABETES EMERGENCIES IN WONOREJO VILLAGE}

\author{
OPTIMALISASI DSME MELALUI PENINGKATAN PENGETAHUAN \\ PENCEGAHAN KOMPLIKASI DAN KONDISI DARURAT DIABETES \\ DI DUSUN WONOREJO
}

\section{Scope: \\ Health}

\author{
Ari Pebru Nurlaily $\square$ Meri Oktariani圆 Anestasia Pangestu Mei Tyas包 \\ ${ }^{1}$ Study Program of Nursing, Faculty of Health Sciences, Universitas Kusuma Husada, Surakarta-Indonesia \\ ${ }^{2}$ Study Program of Nursing, Faculty of Vocational Studies, Universitas Airlangga, Surabaya-Indonesia
}

\begin{abstract}
$A B S T R A C T$
Background: Many elderly convey blood sugar often up and down due to lack of attention to their diet. The condition became urgent because the elderly had previously died from complications accompanied by diabetic ulcers. In the posyandu area of wonorejo healthy elderly, DM disease is one of the diseases that are quite widely suffered by its citizens. Objective: The DSME education program for cadres and the elderly at Posyandu Wonorejo aims to increase knowledge and prevent diabetes complications. Method: This DSME program was conducted in four sessions, namely, session 1 discussing basic knowledge about DM (definition, etiology, classification, etiology, clinical manifestations, diagnosis, prevention, treatment, complications), session 2 discussing DM management including nutrition/diet arrangements, and physical activities/exercises that can be done, session 3 discussing foot care and stress management; and session 4 discusses the prevention of chronic and acute complications, and the patient's access to health care facilities. Results: There was an increase in knowledge and prevention of diabetes complications up to $93,75 \%$ after this activity was conducted.. Conclusion: The program is optimally implemented.
\end{abstract}

\section{A B S T R A K}

Latar belakang: Banyak lansia penderita diabetes melitus mengeluhkan gula darah sering naik turun karena kurang memperhatikan pola makannya. Kondisi tersebut menjadi urgen karena lansia-lansia sebelumnya banyak meninggal karena komplikasi disertai ulkus diabetik. Di wilayah posyandu lansia sehat Wonorejo, penyakit DM merupakan salah satu penyakit yang cukup banyak diderita oleh warganya. Tujuan: Edukasi program DSME kepada para kader dan lansia di Posyandu Wonorejo bertujuan meningkatkan pengetahuan dan pencegahan komplikasi diabetes. Metode: Program DSME ini dilaksanakan dalam empat sesi, yakni sesi 1 membahas pengetahuan dasar tentang DM (definisi, etiologi, klasifikasi, etiologi, manifestasi klinis, diagnosis, pencegahan, pengobatan, komplikasi), sesi 2 membahas penatalaksanaan DM meliputi pengaturan nutrisi/diet dan aktivitas/latihan fisik yang dapat dilakukan, sesi 3 membahas perawatan kaki dan pengelolaan stress; dan sesi 4 membahas pencegahan komplikasi kronis dan akut, dan akses pasien terhadap fasilitas pelayanan kesehatan dengan ceramah dan demonstrasi. Hasil: Setelah kegiatan ini dilaksanakan terjadi peningkatan pengetahuan dan pencegahan komplikasi diabetes hingga 93,75\%. Kesimpulan: Program ini optimal dilaksanakan.

\author{
ARTICLE INFO \\ Received 25 September 2020 \\ Revised 16 December 2020 \\ Accepted 24 April 2021 \\ Online 28 June 2021 \\ *Correspondence (Korespondensi): \\ Ari Pebru Nurlaily \\ E-mail: \\ arifebru1@gmail.com
}

Keywords:

Diabetes mellitus, DSME, Community dedication
Kata kunci:

Diabetes Melitus, DSME, Pengabdian Masyarakat 


\section{PENDAHULUAN}

Diabetes Melitus (DM) adalah penyakit gangguan dalam metabolisme karbohidrat, lemak dan protein sehingga kadar glukosa darah cenderung mengalami peningkatan yang diakibatkan oleh kerusakan sintesis pada sel beta pankreas atau pengeluaran insulin, atau ketidakmampuan jaringan dalam menggunakan insulin (Grossman, et al., 2014). Sedangkan Perkeni (2015) menyatakan DM merupakan suatu kelompok penyakit metabolik dengan karakteristik hiperglikemia yang terjadi karena kelainan sekresi insulin, kerja insulin atau keduaduanya. DM terbagi menjadi beberapa tipe yaitu DM tipe 1, DM tipe 2, DM gestasional dan DM jenis lain. DM merupakan salah satu penyakit kronis yang jumlah penderitanya dari tahun ke tahun cenderung mengalami peningkatan. DM tipe 2 adalah jenis penyakit DM yang paling banyak diderita oleh penduduk dunia (85-95\%), DM tipe 2 adalah DM yang disebabkan oleh terganggunya sekresi insulin dan resistensi insulin.

Berdasarkan data RISKESDAS penduduk dengan usia lebih dari 15 tahun yang terdiagnosa DM mengalami peningkatan menjadi $2 \%$ dari 1,5\% di tahun 2013 (Riskesdas, 2018). Pada Tahun 2030 diperkirakan diabetes melitus menempati urutan ke-7 penyebab kematian dunia. Sedangkan untuk di Indonesia diperkirakan pada tahun 2030 akan memiliki penyandang diabetes melitus sebanyak 21,3 juta jiwa (Depkes, 2013). Sedangkan di wilayah posyandu lansia Wonorejo, penyakit DM merupakan salah satu penyakit yang banyak diderita oleh warganya dari 3 penyakit yang lain, yakni nyeri sendi dan hipertensi.

Manajemen pada penderita diabetes melitus tipe 2 salah satunya adalah dengan pemberian edukasi (Perkeni, 2015). Kegiatan edukasi merupakan salah satu strategi penatalaksanaan penyakit diabetes melitus. Edukasi adalah kegiatan penyampaian pesan kesehatan kepada kelompok atau individu dengan tujuan agar dapat memperoleh pengetahuan yang lebih baik (Habibi, 2015). Pengetahuan penderita mengenai diabetes melitus merupakan sarana yang dapat membantu penderita menjalankan penanganan diabetes selama hidupnya. Untuk itu, semakin banyak penderita mengerti mengenai penyakitnya, maka semakin mengerti bagaimana penderita harus mengubah perilakunya (Norris dalam Sutiawati et al., 2013).

Salah satu bentuk edukasi yang dapat diberikan pada klien DM tipe 2 adalah Diabetes Self Management Education (DSME). Menurut Funnell, et al. (2011), DSME merupakan suatu proses yang memfasilitasi pengetahuan, keterampilan dan kemampuan perawatan mandiri (self care behaviour) yang sangat dibutuhkan oleh penderita DM.

Penelitian DSME yang sudah dilakukan menunjukkan bahwa DSME dapat menurunkan angka insiden DM sampai 58\% (ADA, 2010). Penelitian DSME lainnya yang dilakukan oleh Balagopal, Kamalamma, Patel, dan Misra (2008) di desa Tamilnadu India pada 703 responden yang memiliki faktor risiko DM dan telah didiagnosa dengan DM menunjukkan bahwa program DSME dapat menurunkan KGD puasa sebanyak $11 \%$ pada dewasa pradiabetes, $17 \%$ pada remaja pradiabetes, dan $25 \%$ pada pasien dewasa dengan DM tipe 2 . Program DSME ini dilaksanakan dalam empat sesi, yakni sesi 1 membahas pengetahuan dasar tentang DM (definisi, etiologi, klasifikasi, etiologi, manifestasi klinis, patofisiologi, diagnosis, pencegahan, pengobatan, komplikasi), sesi 2 membahas penatalaksanaan DM menliputi pengaturan nutrisi/diet dan aktivitas/latihan fisik yang dapat dilakukan, sesi 3 membahas perawatan kaki dan pengelolaan stress; dan sesi 4 membahas pencegahan komplikasi kronis dan akut, dan akses pasien terhadap fasilitas pelayanan kesehatan. Keluhan klasik yang sering dijumpai adalah banyak kencing, banyak minum dan banyak ditemukan kondisi kaki lansia yang kering dan keriput serta kuku kaki tumbuh kurang rapi, dan banyak lansia menyampaikan gula darah sering naik turun karena kurang memperhatikan pola makannya. Kondisi tersebut menjadi urgen karena lansialansia sebelumnya banyak yang meninggal karena komplikasi disertai ulkus diabetik. Sedangkan di wilayah posyandu lansia sehat Wonorejo, penyakit DM merupakan salah satu penyakit yang cukup banyak diderita oleh warganya. Sehingga topik pengabdian masyarakat ini sangat cocok untuk dilaksanakan.

Setelah program ini dilaksanakan diharapkan adanya peningkatan pengetahuan pencegahan komplikasi dan kondisi darurat diabetes melitus di Posyandu Lansia Sehat Dusun Wonorejo. Sehingga dengan program DSME lansia mampu mengontrol kesehatannya secara mandiri dan derajat kesehatan lansia meningkat.

\section{METODE}

Pengabdian masyarakat ini dilaksanakan di Posyandu Lansia Sehat Dusun Wonorejo pada bulan Juni sampai dengan Agustus 2020 dengan metode ceramah, tanya jawab dan demonstrasi. Pengambilan data dan monitoring evaluasi dilakukan secara observasi dan indept interview sebelum dan setelah kegiatan. Media yang digunakan adalah lembar balik DSME dan leaflet. Peralatan dan bahan yang digunakan diantaranya 
masker kain, face shield, termogun, hand soap dan hand sanitizer mengingat kegiatan ini dilaksanakan selama pandemic Covid 19, selain itu untuk menunjang demonstrasi maka disediakan handuk kecil, pemotong kuku, sabun, pelembab kulit (hand \& body lotion) untuk demonstrasi perawatan kaki, dan kertas koran digunakan untuk senam kaki diatebes.

\section{HASIL DAN PEMBAHASAN}

Hasil pelaksanaan pembinaan dan penyuluhan selama 3 bulan yang diikuti oleh 16 peserta (12 lansia dan 4 kader), ternyata kegiatan tersebut mendapatkan respon yang baik oleh peserta. Peserta menjadi lebih mengetahui tentang DSME, dan mengetahui cara pencegahannya komplikasi DM (Gambar 1). Aplikasi DSME dapat diketahui dari pemantauan hasil evaluasi salah satunya dengan meminta peserta untuk melakukan praktek secara mandiri yang dilakukan setiap jadwal posyandu, dan peningkatan pengetahuan lansia terhadap DSME dan aplikasinya diketahui dari observasi langsung dan tidak langsung, dimana sebelum dilakukan penyuluhan tentang DSME, lansia dan kader belum mengetahui mengenai apa yang dimaksud dengan DSME. Tetapi setelah dilakukan penyuluhan tentang DSME, peserta menjadi lebih tahu tentang konsep DSME khususnya pencegahan komplikasi DM ditunjukkan dari laporan hasil pemantauan kader terhadap lansia tindakan dari yang sebelumnya $16,7 \%$.

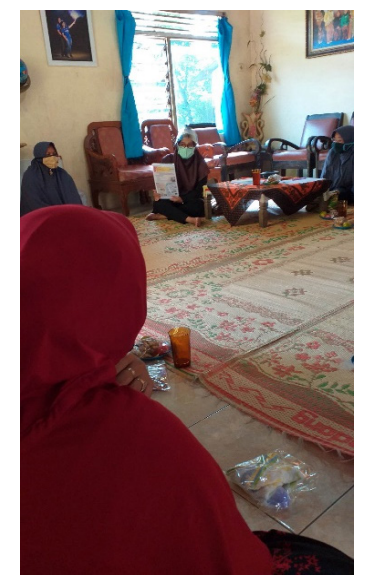

Gambar 1. Penyampaian materi DSME sesi 1 dengan media lembar balik

Berdasarkan tabel 1 di atas bahwa 93,75\% lansia lebih mengetahui konsep diabetes melitus (definisi, klasifikasi, penyebab, tanda gejala, komplikasi dan pencegahan), 93,75\% lansia mengetahui penatalaksanaan diabetes melitus, 93,75\% lansia lebih mengetahui perawatan kaki dan pengelolaan stress, $81,25 \%$ (13 lansia) lebih mengetahui pencegahan komplikasi diabetes melitus, $100 \%$ lansia menerapkan self management untuk memperbaiki life style.

Tabel 1. Perubahan Pemahaman dan Aplikasi Materi Sesi $1 \mathrm{~s} / \mathrm{d} 4(\mathrm{n}=16)$

\begin{tabular}{lcc}
\hline \multicolumn{1}{c}{ Materi dan Sesi } & Pre & Post \\
& & \\
\hline $\begin{array}{l}\text { Sesi } 1 \text { : Konsep diabetes melitus } \\
\text { Sesi } 2 \text { : Penatalaksanaan diabetes }\end{array}$ & $16,7 \%$ & $93,75 \%$ \\
melitus & $0 \%$ & $93,75 \%$ \\
$\begin{array}{l}\text { Sesi } 3 \text { : perawatan kaki dan } \\
\text { pengelolaan stress }\end{array}$ & $0 \%$ & $93,75 \%$ \\
$\begin{array}{l}\text { Sesi } 4 \text { : pencegahan komplikasi } \\
\text { diabetes melitus }\end{array}$ & $0 \%$ & $81,25 \%$ \\
$\begin{array}{l}\text { Aplikasi DSME dan perbaikan life } \\
\text { style }\end{array}$ & $18,75 \%$ & $100 \%$ \\
\hline
\end{tabular}

Data yang ditemukan di lapangan menunjukkan pengetahuan lansia meningkat hingga $93,75 \%$, pada awalnya para lansia belum memahami DSME dan pentingnya melakukan manajemen diri. Beberapa lansia terlihat cukup baik kondisinya walaupun menderita DM, hal tersebut dikarenakan tekad untuk tetap sehat. Namun demikian, perawatan mandiri sangatlah penting dipersiapkan dan dilakukan sejak dini untuk mencegah komplikasi lebih lanjut, utamanya perawatan kaki dan pola diet. Semua lansia mengatakan tidak pernah melakukan perawatan kaki seperti mengoleskan pelembab atau mencuci kaki secara rutin, terkadang tidak mengenakan alas karena mengikuti kebiasaan sehari-hari. Dietnya pun masih sekedarnya yang menyebabkan gula darah tidak stabil. Adapun komponen perawatan kaki menurut IWGDF (2015) ada 6 komponen yang perlu diperhatikan, di antaranya adalah inspeksi kaki harian, menjaga kaki bersih dan kering, menjaga kelembapan dan kelembutan kaki, memotong kuku yang sejajar dengan ujung jari dan lurus, perlindungan dan pertolongan pertama pada trauma kaki, pemilihan sepatu dan kaos kaki. Setelah penyampaian sesi 1 dan 3 program DSME, lansia lebih paham pentingnya perawatan kaki dan pengaturan diet DM (Gambar 2). Menurut Agustiningrum \& Kusbaryanto (2019) sesuai teori Orem Self Care Agency perlu ditingkatkan oleh individu karena self care membutuhkan pembelajaran, pengetahuan dan skill, pada program ini lansia tidak hanya diberikan edukasi sesuai sesi 1, 2, 3, dan 4 saja, akan tetapi juga melatih skill dengan demonstrasi seperti mencuci kaki yang benar, mengeringkan kaki, memotong kuku yang benar, melembabkan kaki, dan melakukan senam kaki DM. penulis berpendapat bahwa dengan memberikan keterampilan penatalaksanaan DM (diet DM 
dan aktifitas fisik pasien DM) dan pencegahan komplikasi dengan perawatan kaki yang benar serta pengelolaan stress, klien DM dapat mengelola penyakitnya dengan baik, sehingga self agency klien meningkat, sejalan dengan pengertian Funnell et al. (2011) yang menyebutkan suatu proses berkelanjutan yang dilakukan untuk memfasilitasi pengetahuan, keterampilan, dan kemampuan klien DM untuk melakukan perawatan mandiri. Hal ini sejalan dengan penelitian yang menyatakan adanya pengaruh program DSME terhadap peningkatan pengetahuan, peningkatan latihann fisik, peningkatan pola makan, dan peningkatan monitoring gula darah sebesar $p$ value $<0,05$. Didukung oleh hasil penelitian Umaroh (2017) pada penelitiannya yang berjudul Pengaruh DSME melalui media kalenderterhadap kepatuhan perawatan kaki klien diabetes melitus tipe 2 di Balai Pengobatan Muhammadiyah Lamongan.

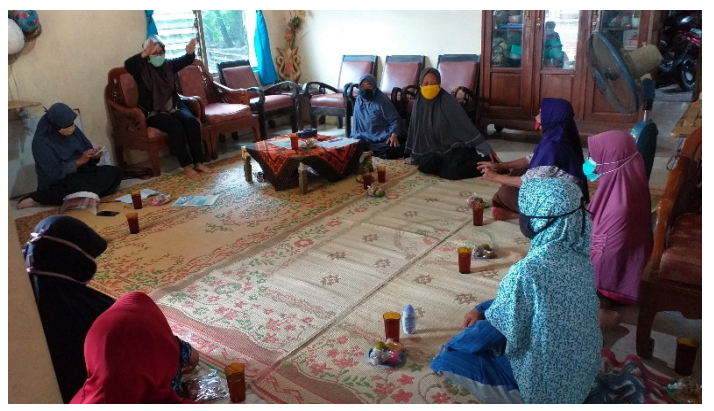

Gambar 2. Menunjukkan proses senam kaki DM

\section{KESIMPULAN DAN SARAN}

Kegiatan edukasi program DSME ini berhasil dilaksanakan dengan optimal. Hal tersebut ditunjukkan dengan indikator peningkatan pemahaman konsep diabetes melitus pada kader dan lansia hingga 93,75\%. Selain itu, sebanyak 93,75\% lansia dapat mengetahui penatalaksanaan diabetes melitus serta perawatan kaki dan pengelolaan stress. Sebanyak 81,25\% lansia juga dapat mengetahui pencegahan komplikasi diabetes melitus setelah mengikuti kegiatan pengabdian masyarakat ini. Seluruh lansia (100\%) peserta kegiatan ini juga menerapkan self management untuk memperbaiki life style.

Pengabdian masyarakat tentang upaya peningkatan pengetahuan DSME dan pencegahan komplikasi DM di Posyandu Lansia Sehat Dusun Wonorejo dapat dilakukan secara berkelanjutan oleh kader setempat minimal 2 bulan sekali.

\section{UCAPAN TERIMA KASIH}

Penulis mengucapkan banyak terima kasih kepada semua pihak yang telah mensukseskan kegiatan ini, para kader dan juga lansia dari
Posyandu Lansia Sehat Dusun Wonorejo. Penulis menyatakan tidak ada konflik kepentingan dengan pihak-pihak yang terkait dalam kegiatan pengabdian kepada masyarakat ini.

\section{DAFTAR PUSTAKA}

American Diabetes Association (ADA). 2010. Diagnosis and Classification of Diabetes Mellitus. Diabetes Care Vol. 33. Pp. 62-69.

Agustiningrum, R., \& Kusbaryanto. 2019. Efektifitas Diabetes Self Management Education Terhadap Self Care Penderita Diabetes Mellitus: Literature Review. Jurnal Keperawatan Respati Yogyakarta Vol. 6(2). Pp. 558-563.

Depkes. 2013. Diabetes Melitus Penyebab Kematian Nomor 6 Di Dunia: Kemenkes Tawarkan Solusi Cerdik Melalui Posbindu.

Funnell, M.M., et al. 2011. National standarts for diabetes self-management education. Diabetes Care Vol. 34(1). Pp. 89-96.

Grossman, S., et al. 2014. Porth's pathophysiology. Philadelphia: Lippincott William \& Wilkins.

Habibi. 2015. Pengaruh Pemberian Edukasi Terhadap Tingkat Pengetahuan Perawat Dalam Aplikasi Modern Dressing pada Luka Diabetes Melitus di RSUD pemangkat Kabupaten Sambas Kalimantan Barat. Jurnal Proners Vol. 3(1). Pp. 1-9.

IWGDF. 2015. The 2015 IWGDF Guidence Documents on Prevention and Management of Foot Problem in Diabetes: Development of an Evidence-based Global Concensus on the Diabetic Foot.

Perkeni. 2015. Pengelolaan dan pencegahan diabetes melitus tipe 2 di indonesia. Jakarta: Perkumpulan Endokrinologi Indonesia. Available from: http://pbperkeni.or.id. Diakses: 04 Agustus 2020.

Riskesdas. 2018. Diabetes Melitus. Available from: https://pusdatin.kemkes.go.id/ article/ view/20111800001/diabetes-melitus.html. Diakses: 3 September 2020

Sutiawati, M., Nurhaedar, J., \& Yustini. 2013. Pengaruh Edukasi Gizi Terhadap Pengetahuan Pola Makan Dan Kadar Glukosa Darah Pasien Diabetes Melitus Tipe 2 di RSUD Lanto' Dg Pasewang Jeneponto. Media Gizi Masyarakat Indonesia Vol. 2(2). Pp. 78-85.

Umaroh, L. 2017. Pengaruh Diabetes Self Management Education (DSME) Melaui Media Kalender Tehadap Kepatuhan Pemanfaatan Kaki Klien Diabetes Melitus Tipe 2 Di Balai Pengobatan Muhammadiyah Lamongan. Skripsi. Surabaya: Sarjana Universitas Airlangga. 